\title{
Pilgrimage Sites in Slovakia as the Base for the Formation of Ecomuseums - Case Study of L'utina Pilgrimage Site
}

\author{
Tomáš Pasternák ${ }^{A *}$, Viktor Verba ${ }^{A}$ \\ Received: January 8, 2018 | Revised: May 17, 2018 | Accepted: May 20, 2018 \\ DOI: $10.5937 / 22-16619$
}

\begin{abstract}
Religious tourism is one of the oldest types of tourism and is connected with visiting various sacred places of religious significance. In Slovakia, the tradition of pilgrimage has rich history, as evidenced by a large number of pilgrimage sites that attract many pilgrims from Slovakia and abroad and still have their irreplaceable significance. However, these religious centres are not separated from other natural and cultural-historical attractions, as they together form the genius loci of a particular territory. The aim of this paper is to link the pilgrimage site with individual natural and cultural-historical interests in its surrounding in the context of the ecomuseum phenomena, which are now becoming more and more aware of the inhabitants and local communities in individual regions. Linking these locations should improve people's awareness of the territory they live in while making these places more attractive for visitors/pilgrims. Part of the paper is a case study on the example of the largest pilgrimage site of Greek Catholics in Slovakia - L'utina, which has the largest potential to become a leader within a religious tourism and within a formation of ecomuseum in the region of eastern Slovakia in the context of implementation of projects and realization of activities directly in this pilgrimage site and surrounding attractive places.
\end{abstract}

Key words: pilgrimage sites, ecomuseum, territory inheritance, Slovakia, L'utina

\section{Introduction}

The issue of religious tourism is primarily connected to sacred places/pilgrimage sites of religious significance and has been studied by many authors. Among the most important are works of Rinschede (1992), Cohen (1992), Stoddard (1997), Jackowski (2000), Liszewski (2000), Matlovič (2001), Vukonic (2006), Krogmann (2007), Collins-Kreiner (2010), Stausberg (2011), Soljan (2012), Matlovičová et al. (2015), etc. In Slovakia, pilgrimage sites are a very important part of the religious life of the country's inhabitants. Most of the pilgrimage sites in this area arose during the $16^{\text {th }}$ and $17^{\text {th }}$ century, that is, during the period of recatholiza- tion processes. The tradition of pilgrimage and the oldest pilgrimage sites, however, date back to the Middle Ages. These pilgrimage sites include Svätý Beňadík ( $11^{\text {th }}$ century), Levoča ( $13^{\text {th }}$ century), Košice $\left(13^{\text {th }}\right.$ century) and Spišský Štvrtok ( $14^{\text {th }}$ century). In the $16^{\text {th }}$ century, more than 30 significant pilgrimage sites were established in Slovakia, including Obišovce ( $16^{\text {th }}$ century), Marianka ( $17^{\text {th }}$ century), Šaštín ( $17^{\text {th }}$ century), Staré Hory ( $17^{\text {th }}$ century), Nitra ( $18^{\text {th }}$ century), Trnava ( $18^{\text {th }}$ century), Lutina ( $19^{\text {th }}$ century), Gaboltov $\left(20^{\text {th }}\right.$ century) and Litmanová (20 ${ }^{\text {th }}$ century) (Fekete, 1947; Lenčiš, 2000).

\footnotetext{
A Department of Geography and Applied Geoinformatics, University of Prešov, Ul. 17. novembra 1, 08116 Prešov, Slovakia; tomi. paster@gmail.com, verba.viktor@gmail.com

* Corresponding author: Tomáš Pasternák, e-mail: tomi.paster@gmail.com
} 
Pavicic et al. (2007) claim that pilgrimage sites are sometimes located far from the people who come to these places, so sometimes the length and difficulty of the journey itself is spiritually significant. Similarly, pilgrimage sites are perceived by anthropologists Victor Turner and Edith Turner (1973 in Pavicic et al., 2007). In their view, pilgrimage sites are usually located "out there". This peripheral location is geographic and cultural; these sites are on the brink of human centres and the socio-political centres of society.

According to Tirpák et al. (2015), the impact of pilgrimage sites today extends beyond the regional and national borders, and participation in the pilgrimage is an expression of Christian existence because it demonstrates living faith and expresses great trust at the same time.

In the context of pilgrimage sites, Catholicism has a strong tradition of so-called Marian pilgrimage sites. They were set up in the places of the Virgin Mary apparitions, which are often accompanied by miraculous healings and events, as well as messages for visionaries. The most prominent examples of such pilgrimage sites are Lourdes, Fatima, Medjugorje, Loreto, Czestochowa and others (Vukonič, 2006).

The aim of the paper is to point to pilgrimage sites as part of the territory, its history and present. A very interesting concept highlighting the richness of the area (natural and cultural-historical) is an ecomuseum, managed by the local community of inhabitants for the purpose of protecting, raising and presenting the local heritage. The very idea of connecting the pilgrimage site with significant natural and culturalhistorical uniqueness in its surroundings into a single unit in the form of an ecomuseum is a new idea that authors have not yet met within a study of a large number of papers.

The concept of ecomuseums itself is not at present a novelty; their history dates back to the 1970s in France. In many countries, ecomuseums had their predecessors, but they brought new ideas and practices to museums and inheritance of the territory in-situ, in particular the involvement of the inhabitants of the region themselves in activities and management of this protection. In the $21^{\text {st }}$ century, ecomuseums have become a global phenomenon aimed at protecting the natural and cultural heritage in a particular territory and focusing primarily on local communities that should be the main actors in this protection and presentation.
Corsane and Holleman (1993, in Davis 2011, p. 80) present an ecomuseum as " $m u$ ch larger territory in a fairly open-ended manner. Here the territory is not simply defined in geographical or administrative terms, but rather as any whole unit where the inhabitants share a common way of life, culture, occupation or traditional custom. Run from a central headquarters the ecomuseum has a series of 'antennae' within the territory of the museum. These antennae form a network through which the activities of information-gathering, research, display and education can be performed."

Establishing an ecomuseum is a dynamic process through which communities are able to identify, preserve, interpret and manage their natural and cultural heritage resources within the framework of sustainable development. The ecomuseum is based on social consent and is defined by geographical environment that can cross political boundaries (Borrelli \& Davis, 2012).

Slovakia is still only at the beginning of the initiative of ecomuseums, and it can use already existing projects from other countries, whether it is Poland or other countries with a well established eco-politics policy. Nowadays, we can consider the ecomuseum in Slovakia only the Hont Ecomuseum, which is a project of cooperation of the local action groups of the MAS Zlatá cesta and the MAS Partnership of Krtís Poiplie, realized in 2011-2012. In the East Carpathian region, three ecomuseums are being developed: "In the Footsteps of the Smugglers" Ecomuseum (Chodníkom pašerákov), "In the Footsteps of Duchnovič" Ecomuseum (Po stopách Duchnoviča) and the "Shape of fire" (Podoby ohňa) Ecomuseum. Representatives of these ecomuseums (municipalities, local entrepreneurs, regional development agencies) actively cooperate with representatives of the Polish ecomuseums in the Biesczady Region with the support of the Biesczady Foundation and the Association for the Development and Promotion of the SubCarpathian Region (Klamár, 2012).

Pointing to the phenomenon of the ecomuseum and to the pilgrimage site as its central point of interest is the main goal of this paper, which is outlined not only in the theoretical phase, but also applied in a case study at the most important pilgrimage site of the Greek Catholic Church in Slovakia in Lutina (Sabinov, Prešov Region) and at the same time authors created a model of the ecomuseum, which includes other important natural and cultural-historical sites and monuments in its immediate vicinity. 
There are several models and types of ecomuseums proposed by several authors within the framework of the current existing ecomuseums in the world (Rivard, 1985; Mayrand, 2000; Maggi \& Faletti, 2000; Davis, 2005, 2011). In the case of the area authors have studied, they applied the model proposed by Davis (2005), who compares an ecomuseum to a necklace, combining selected elements of the heritage, where the ecomuseum presents fiber and individual elements of the heritage present beads or pearls. Thus, if we understand an ecomuseum as a fiber, then it can be perceived as a mechanism that holds the various elements (pearls, special places, cultural prints) that make the places unique (Figure 1).

While identifying and selecting places of natural and historical interest near the pilgrimage site of Lutina, authors mainly took into account its road accessibility. According to Michniak (2014), in addition to the necessary natural or cultural-historical presumptions, transport availability is considered to be one of the most important factors in the development of short-term tourism. For this reason, researchers created a circle of distances up to $35 \mathrm{~km}$ from the pilgrimage site (Lutina), which helped us to generate a list of interesting places. After final summary, a careful selection of attractive places followed. The selection also included the search and study of litera- ture focusing on issues of ecomuseums, pilgrimage sites, tourism and the characteristics of the studied area. This has, in many cases, helped authors to identify places or attractions that are not generally known and have only regional value, but they can appeal to a potential visitor.

A substantial part of the whole research was the realization of field observations, which consisted of a visit to the pilgrimage site of Lutina and some natural and historical attractions in its surroundings. This field research mainly served for mapping and evaluating the studied area and for collecting the necessary photographic material. An important part of the research was the creation of cartographic outputs made in the specialized geographic information system QGIS.

From a methodological point of view, our research consisted of individual partial methods and techniques. The most important ones were:

- Analysis and synthesis of texts

- Generalization of texts

- Evaluation

- Field research

- Observations

- Collection of photographic material

- Methods of cartographic interpretation

- Case study application

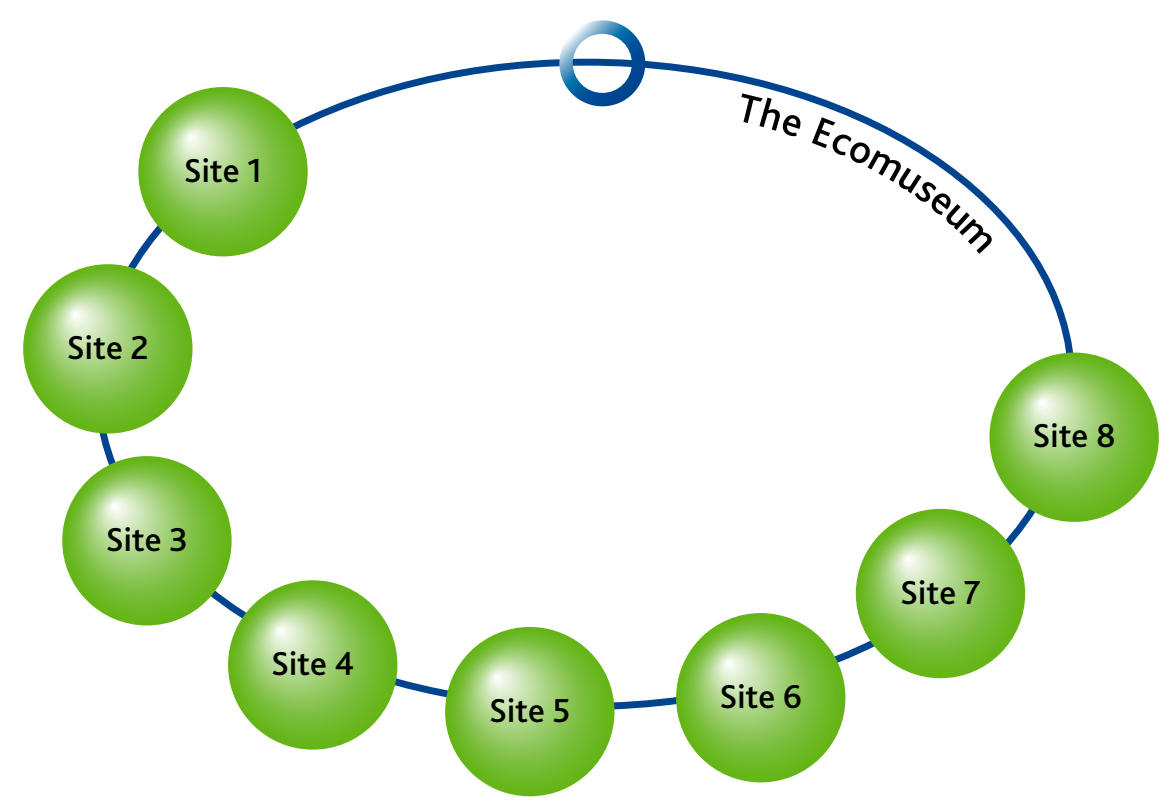

Figure 1. The necklace model for the ecomuseum Source: adapted from Davis, 2005 


\section{Pilgrimage sites in Slovakia}

As the research itself is carried out at the pilgrimage site of Lutina, it is necessary briefly point out some general information about the pilgrimage sites in Slovakia. From the point of view of pilgrimage sites localization in Slovakia, Fekete (1947) follows two main concentrations. The first is the area in the southwestern part of Slovakia in the Danubian Lowland; the second is the region of eastern Slovakia with the historical regions of Spiš, Šariš and Zemplín, crossing the border between Catholics of Western Rite (Roman Catholics) and Eastern Rite (Greek Catholics). In other parts of Slovakia, the number of pilgrimage sites is low. Among such examples is the Central Slovakia Region (Banská Štiavnica, Staré Hory), southern Slovakia (Bíňa) or Orava and Kysuse Region (Turzovka) (Fekete, 1947; Verba \& Pasternák, 2016b).

In a Fekete view (1947), such an irregularity in the distribution of pilgrimage sites caused several factors, among the most important are:

a) The surface of Slovakia - most of the pilgrimage sites are located at the outskirts of mountains, which was not a coincidence, as they depended on a sufficient number of pilgrims coming from densely populated areas, such as lowlands,

b) Geographical location - pilgrimage sites were established along the important roads. Such examples are pilgrimage sites in eastern Slovakia, which were concentrated along a trade route of the Torysa River (Obišovce, Bertotovce, Prešov, Vel'ký Šariš, Lutina, Čirč), c) Historical (human) factors - the direct factor of the birth of a pilgrimage site is a man himself, the moment he began to wander there. Donations by donors for the development and maintenance of pilgrimage sites were also important.

In terms of dedication, Matlovič (2001) distributes pilgrimage sites in Slovakia into following two categories:

1. Pilgrimage sites connected to the worship of the Lord's Crucifixion (the crucifixion of Jesus Christ, the Son of God, on the cross in Jerusalem) - calvarias; built from the 16th century to simulate the conditions in Jerusalem,

2. Pilgrimage sites connected to the cult of Our Lady (the cult of Mary, the Mother of Jesus Christ, who is worshiped by believers within Christianity) - the most numerous group of pilgrimage sites.

An important position within Slovak pilgrimage sites have the pilgrimage sites of the Greek Catholics, located exclusively in the eastern part of the country. The eight most important ones are Lutina, Litmanová, Čirč, Šašová, Buková Hôrka, Rafajovce, Krásny Brod and Klokočov (Figure 2), which became religious centres for incoming pilgrims and places of special religious belief of this specific religious group (Verba \& Pasternák 2016b). Its spirituality has its roots in Eastern Christianity, brought to Slovakia by the Byzantine mission of Sts. Cyril and Method, whose traces were most marked in eastern Slovakia (Petrík et al., 2012).

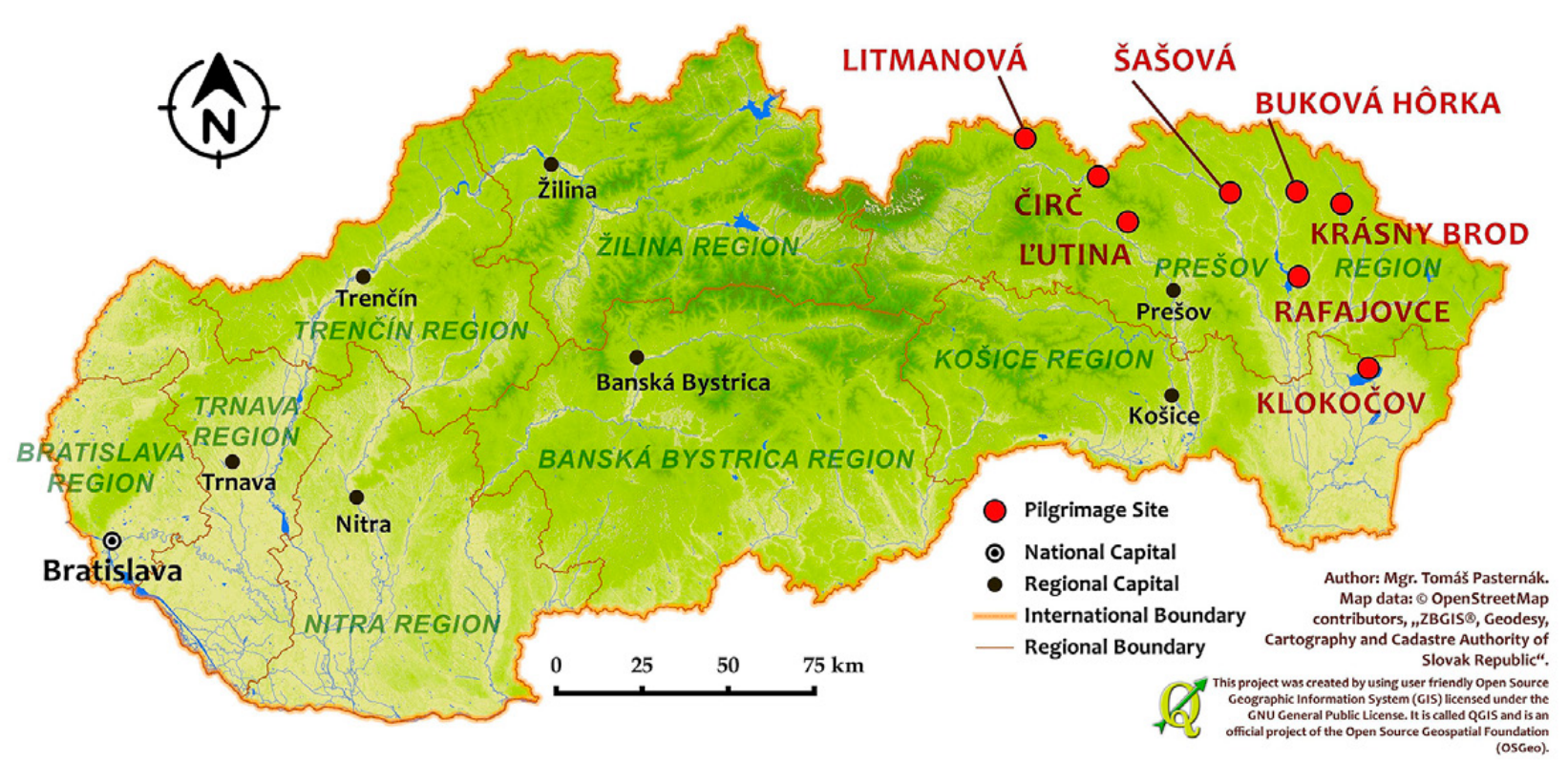

Figure 2. The most important Greek Catholic pilgrimage sites in Slovakia 


\section{Studied area - the pilgrimage site of L'utina and its surrounding}

\section{History and present of L'utina pilgrimage site}

Lutina is located in the northeastern part of Slovakia, Sabinov District, Prešov Self-Governing region. From the capital, Lutina is $420 \mathrm{~km}$ away. From the county town of Prešov (the $3^{\text {rd }}$ largest city of Slovakia) is $30 \mathrm{~km}$ away and Košice ( $2^{\text {nd }}$ largest city of Slovakia) is $65 \mathrm{~km}$ away. From the transport point of view, Lutina is directly accessible by car and bus and indirectly by rail (Pečovská Nová Ves village $-5 \mathrm{~km}$ ). The nearest Slovak airports with an international character are located in the cities of Košice (74 km) and Poprad (109 $\mathrm{km}$ ). L'utina is also accessible by hiking trails through the Čergov Mountains.

The history of Lutina as a pilgrimage site began to be written in 1851 when a sequence of miraculous events took place here. On the morning of August 19, at the feast of the Lord's Transfiguration, Zuzana Fekete and her three children went to the woods called Havranka. Upon returning home, she saw a great glow at its rim, and a solemnly dressed bishop who resembled St. Nicholas from the icon of local iconostasis. After other miraculous events, when the saint asked for the construction of the chapel dedicated to the Assumption of the Blessed Virgin Mary, he gave Zuzana the icon of the Mother of God, which, after being locked in the treasury, reappeared with this woman on the second day. Based on this miracle, all villagers believed. After the time of the investigation, Pope Pius IX awarded (1855) the opportunity to obtain plentiful indulgences for believers travelling to Lutina. There appeared several miraculous healings that were documented. After the prohibition of the Greek-Catholic Church in 1950, the pilgrimage to Lutina was stopped. The reconstruction took place after 1968. An important event for Lutina was the promotion of the local church and

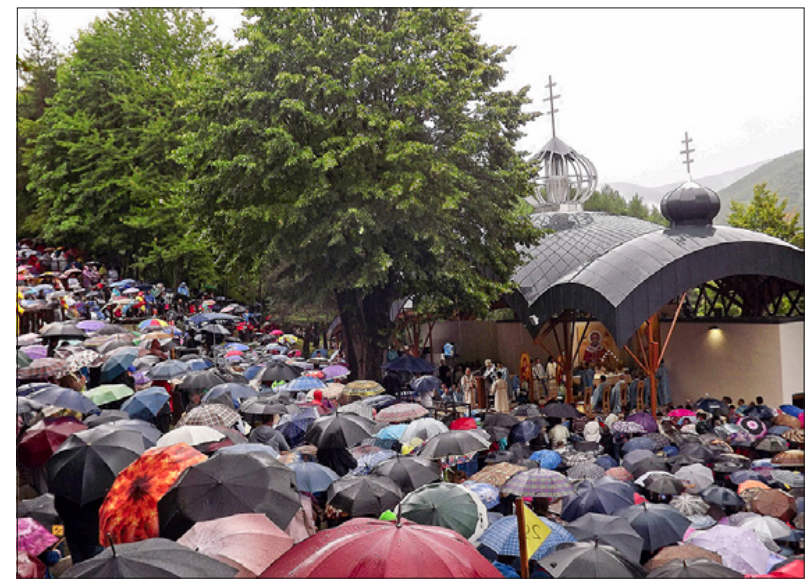

Figure 3. Marian hill in L'utina during the pilgrimage in

August 2017

Photo: Viktor Verba adjacent buildings at the Basilica Minor, which was awarded by Pope John Paul II in 1988 (Dancák, 2010; Verba \& Pasternák, 2016a).

Lutina is today a Marian pilgrimage site (the cult of the Virgin Mary) and the largest and most visited Greek-Catholic pilgrimage site in Slovakia (Figure 3). Over the last decade, it has been given special attention by various actors, not only at the religious (spiritual) level, but also at the material and technical level related to the complex architectural and dispositional transformation of the infrastructure, which brought a significant movement of religious tourism in this region (Figure 4). The most important events of the current period include (Figure 5):

- Affiliation of the pilgrimage site with the Pontifical Basilica of Santa Maria Maggiore in Rome with the privilege of indulgences (2010),

- Deposition and permanent exhibition of the rare relics of several saints: St. John Paul II, St. Nicholas, St. Faustina, blessed Pavol Peter Gojdič, blessed Vasil' Hopko and others,

- Extension of the basilica and the reconstruction of the whole complex in its surroundings,

- Opening of the open air museum of wooden churches (2011),

- Interior decoration of the basilica with oversized mosaics (2013),

- Restoration of the liturgical space on the Marian hill,

- Establishment of permanent spiritual care for incoming pilgrims throughout the year,

- Organizing the pilgrimage of various groups of believers in the course of the year (pilgrimage of Roma people, pilgrimage of priests, pilgrimage of families, pilgrimage of catholic schools, etc.),

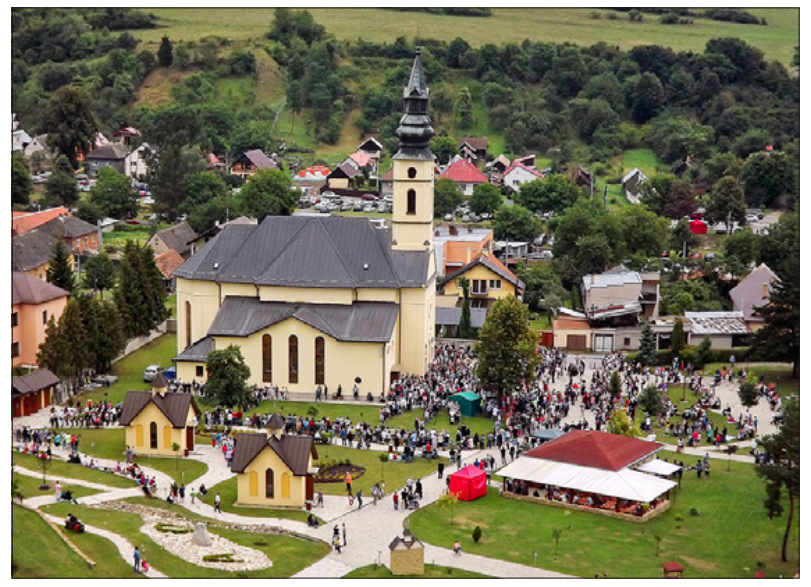

Figure 4. Basilica minor and chapels in L'utina during the pilgrimage in August 2017 Photo: Viktor Verba 


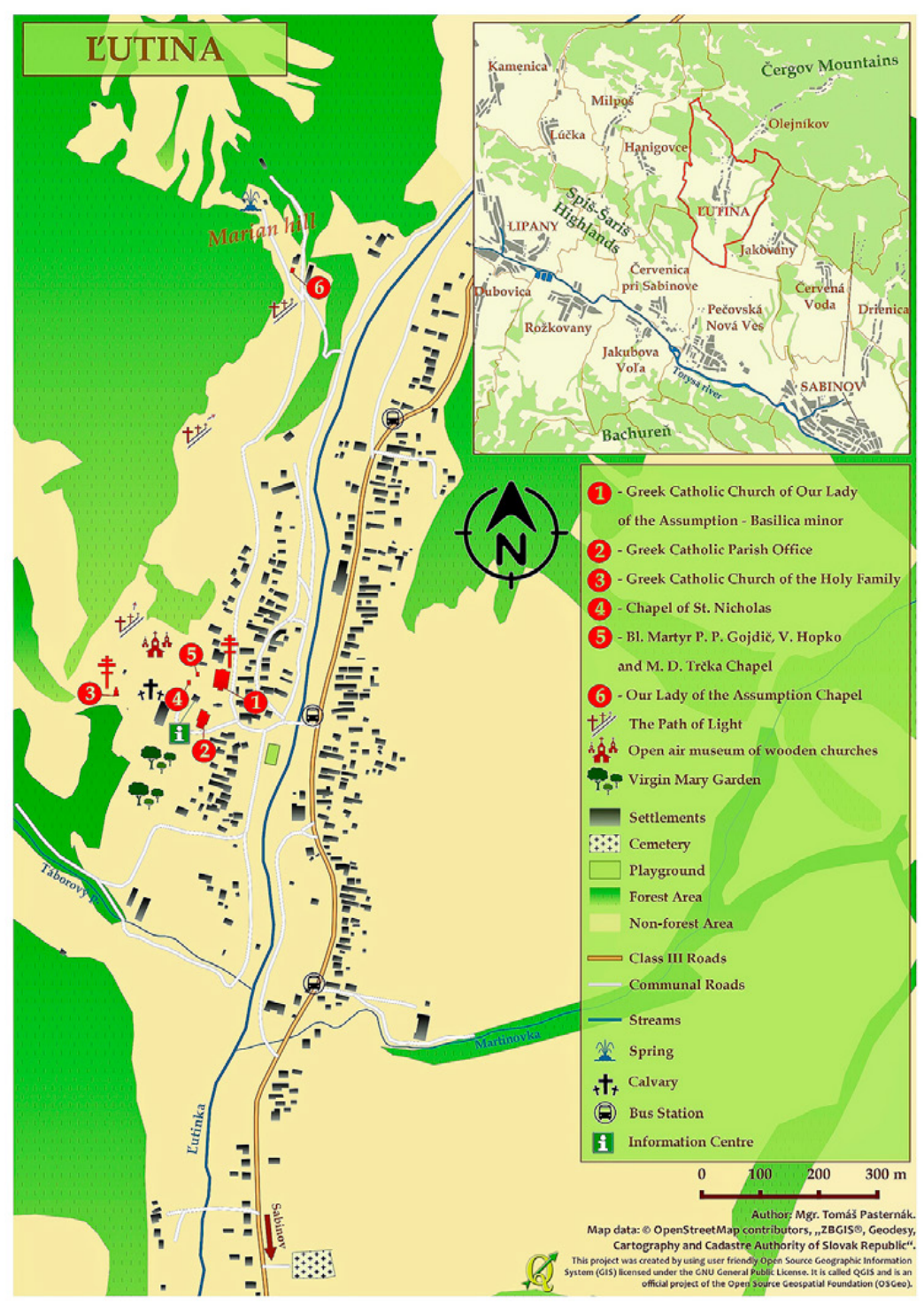

Figure 5. L'utina pilgrimage site at present

- Establishment of a tourist information centre,

- Internet coverage of the pilgrimage site with regular online broadcasting via the camera system (2016),

- Building a pilgrimage house and new social facilities,

- Construction of the Holy Family wooden church (with a view-tower) according to the drawings of the original wooden church from the 18th century (2015),

- Construction of the Virgin Mary Garden with chapels and copies of Greek-Catholic Marian icons from the pilgrimage sites in Slovakia and abroad (2017),

- Connection of Lutina to the network of hiking trails (Čergov Mountains),

- Involvement of Lutina in the international project "St. Mary's Pilgrimage - Light of the East" in order to complete the pilgrim's infrastructure and to cre- ate an international pilgrimage/tourist route linking selected pilgrimage sites in eastern Slovakia and Poland (2017).

Identified and selected interesting places of natural and historical interest near the pilgrimage site of Lutina are in most cases attractive even in a particular view, but their connection with the pilgrimage site of Lutina changes their essence and gives them different, spiritual dimension (Figure 6). Most interestingly, all these places are connected in the conception of the ecomuseum, where they also receive the protection and enhancement of this local heritage, and, last but not least, the local community of the inhabitants in individual places also acquires an important role or function as it is important for the establishment and functioning of the ecomuseum. The following chart presents the basic information of these interesting places: 


\section{Significant locations near L'utina pilgrimage site}

\section{Čergov Mountains}

A visited site of significant natural value. Within the mountain range, several protected small-scale areas have been allocated. These areas include national nature reserves Čergovský Minčol, Čergovská javorina, Hradová hora, Pramenisko Tople, etc. From the point of view of tourism, Čergov is an important region with a tourist value and ski traditions.

\section{Sabinov}

In the past, the town was a member of the five eastern Slovak royal towns of Pentapolitana (Košice, Prešov, Sabinov, Bardejov, Levoča). There lived a large Jewish community in the past. Jewish wartime issues were also portrayed in the famous Oscar-winning film The Shop on Main Street (1966), which was filmed in Sabinov.

\section{Pečovská Nová Ves}

The local landowners left 4 mansions and a classicist manor-house. The oldest monument of the village is the Renaissance Roman Catholic Church of St. Andrew. The village was also connected to significant Jewish community. The remains of Jewish population include the Jewish cemetery and the synagogue.

\section{Hanigovce}

This village is known due to the presence of Hanigovce Castle, which was located on the important trade route to Poland. The castle was built between 1322 and 1342 on the site of the original wooden castle. Reconstruction and archaeological research have been carried out at the castle recently.

\section{Kamenica}

This village is known thanks to the presence of Kamenica Castle, which was located on the important trade route to Poland. Reconstruction and archaeological research have been carried out at the castle recently.

\section{Krivany}

This village is known due to the preserved folklore traditions and the presence of the preserved water mill from the 17th century. In 1984, the water mill was included in the list of technical monuments.

\section{Prešov}

Prešov was an important centre of culture and education with the nickname "Athens on the Torysa River". The historical centre was declared a town reservation in 1995 with the whole complex of valuable building monuments. Prešov is also a significant religious centre of the Greek-Catholic, Orthodox and Evangelical believers.

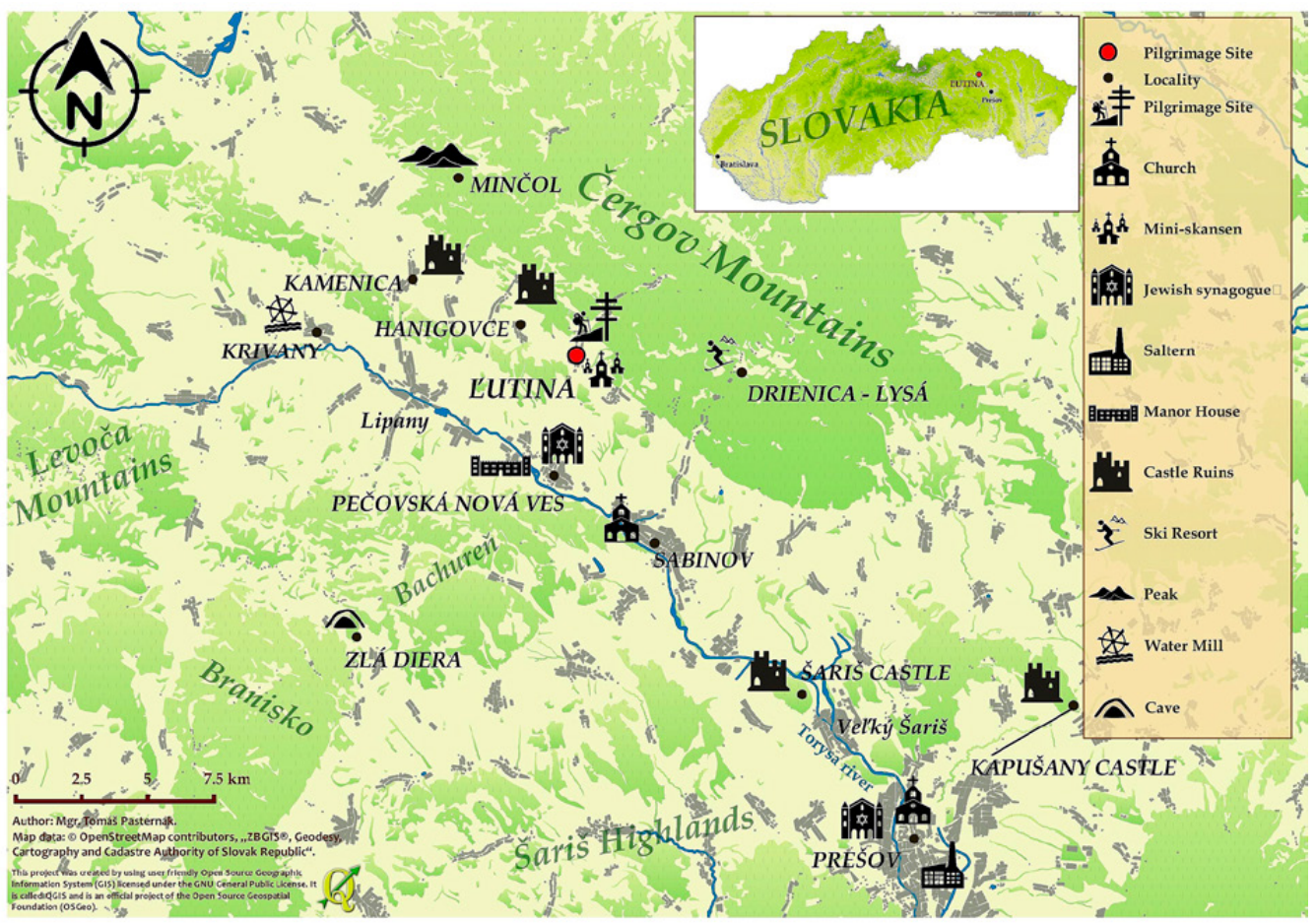

Figure 6. L'utina pilgrimage site and interesting places around within the ecomuseum model 


\section{Basic geographic characteristics and history of the village of L'utina}

The village is located at the southern foot of the Čergov Mountains at an altitude of about $425 \mathrm{~m}$ above sea level. The centre of the village is crossed by the Lutinka River. From the administrative division point of view, the municipality belongs to the Prešov Region and the Sabinov district, whose centre is the town of Sabinov, which is $10 \mathrm{~km}$ away from Lutina. According to the latest data available in 2016, 497 inhabitants live there. During the last census in 2011, most of inhabitants considered themselves in terms of ethnic structure as Slovaks (93.18\%) and Ruthenians (1.28\%). In terms of religious structure, $77.4 \%$ were Greek Catholics, $10.7 \%$ Roman Catholics and 3.6\% Orthodox believers (SODB, 2011).

For the first time, Lutina is mentioned in 1330. The village was located in the Šariš County, the centre of which was the Old Castle (Vel'ký Šariš). It originated in the colony of Pečovská Nová Ves as part of the New Castle (Hanigovce). One of the first written records of Lutina dates back to 1341, where it is referred to as Lethenya. In the documents of the $14^{\text {th }}-16^{\text {th }}$ century, the village is found in several Hungarian forms of the original name of Lutina. In the Middle Ages, the village was located on the important trade road to Cracow, Poland. At the end of the $16^{\text {th }}$ century, Lutina was a medium-sized village with a vassal population. From the $14^{\text {th }}$ to $16^{\text {th }}$ century, a noble castle called Hrádok was located above the village. The inhabitants dealt with agriculture, livestock and fruit farming. In the $18^{\text {th }}$ and $19^{\text {th }}$ century, there was a paper mill. In the interwar period, inhabitants worked in agricul- ture and forests. There were 3 saw factories in the village, and the forest railway crossed the village during this time (Uličný, 1990; Verba \& Pasternák, 2016a; Internet 1$)$.

\section{Pilgrimage site as an impulse for the ecomuseum formation}

The studied pilgrimage site of Lutina with all existing spaces and localities was planted in the Davis model of ecomuseum, characterized in Methods and Data section. It is its main component and centre. While selecting other interesting sites and places in the vicinity from the natural and historical-cultural heritage point of view, authors also applied the mechanism described in the previous Methods and data section. On the basis of their application, authors have created a list of important places that were put into the Davis model perceiving an ecomuseum as a necklace (Figure 7).

Widawski (2011) argues that the concept of the ecomuseum best expresses the interactions between the three pillars: territory, society (community) and historical heritage.

In spite of the prefix of "eco", most of the surveys focus not only on the natural environment but also on human relationships and efforts within particular specific environment. Here we can understand the environment as a combination of natural landscape (landscape mosaic of meadows and forests) and environment created or transformed by a man. Therefore, in the ecomuseum, environment encompasses material elements such as settlement and people living there, individual buildings, cultural artifacts, models

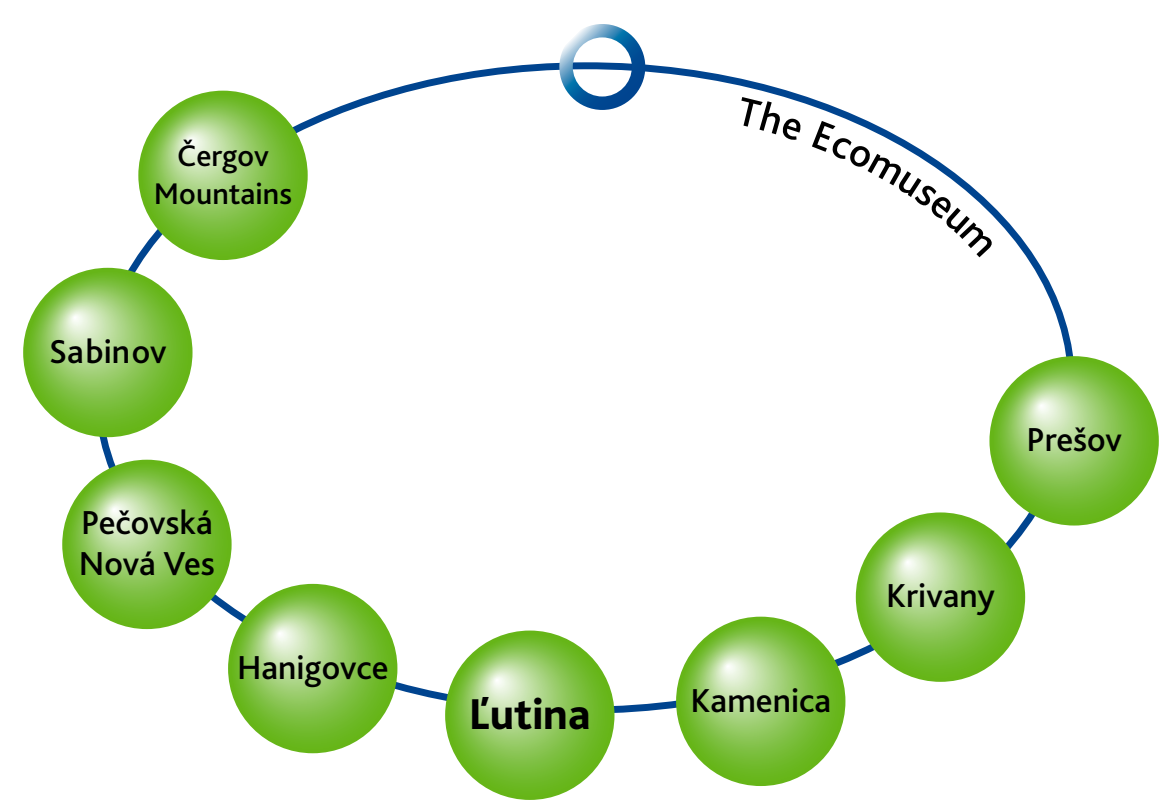

Figure 7. The necklace model for the ecomuseum applied for L'utina pilgrimage site and interesting sites in its surrounding Source: adapted from Davis, 2005 
of land use or animals as well as intangible elements such as traditions, memories, various festivals (Davis, 2011).

Corsane, Davis and Murtas (2009) also emphasize the importance of local inhabitants who should be motivated to perceive the need to protect their heritage and cultural resources as manifestations of their local identity.

Identity is, according to Davis (2011), a concept firmly linked to a place and time, and the heritage of the territory is significant in that it is one of the factors (e.g. ethnicity, religion, language, behaviour) that are used to create community stories. Ecomuseums should have particular interest as local people are responsible for using their inheritance to build the local identity of individuals or communities.

In the Czech Republic, we meet the term cultural historical heritage. This cultural heritage consists of three components which overlap each other, thus creating three thematic circles covering a wide range of disciplines (Figure 8). Landscape heritage refers to the intersection of natural and cultural influences at a particular site, the historical transformations of cultural landscape, the creation of aesthetic value of landscape, the protection and active care of landscape.

Tangible cultural heritage refers to immovable monuments, including documents of folk architecture or industrial architecture, historical and artistic subjects, movable documents on changes in lifestyle. The intangible cultural heritage includes the preservation of historical memories, knowledge and abilities including language and literature, music, dance, customs, traditions, culinary specialties or local names (Foltýn et al., 2008; in Havlůjová et al., 2012).

Therefore, authors have selected sites based on these three components, some of which are in the penetration of two or even in the penetration of all three components.

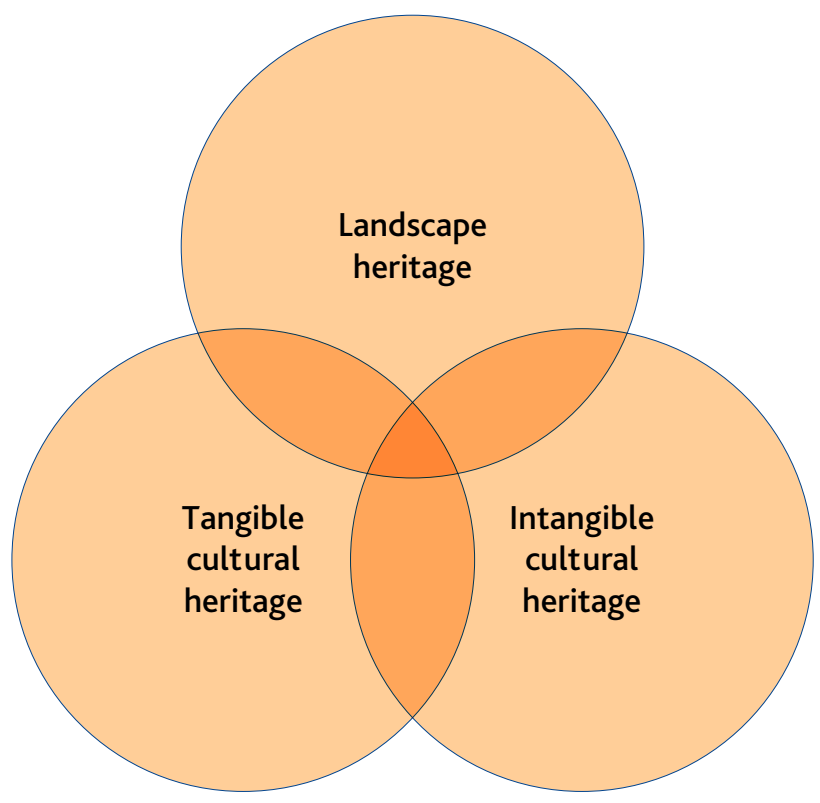

Figure 8. The cultural-historical heritage

Source: Aadapted from Foltýn et al., 2008, in Havlůjová, 2012

\section{Conclusion}

Research on the Greek-Catholic pilgrimage site of Lutina and its surroundings brought several conclusions. First of all, it should be noted that visits to this pilgrimage site during the main pilgrimage or normal working days confirmed our assumptions that this pilgrimage site belongs to the important religious centres and is the destination for many pilgrims from Slovakia and abroad, as evidenced by the numerous crowds of pilgrims coming to this place. Our assumption has also been confirmed that in Lutina, there are several natural or historical attractions within the 35 $\mathrm{km}$ radius of the road, forming together with the pilgrimage site the genius loci of the studied area.

Studying the literature and visiting both the pilgrimage site and interesting places in its surrounding revealed interesting findings about the real wealth of this region. The very location and position of interesting places around the pilgrimage site of Lutina is conditioned by the natural factors as well as the historical development and inhabitants. Most of the natural and cultural-historical attractions that authors have identified in its reach are mainly concentrated south 
and west of Lutina, almost all of which are located in the Torysa valley. In this case, the surface played an important role here: physical-geographical barriers (Čergov Mountains, Bachureň, Levoča Mountains). Some natural or historical attractions identified near the pilgrimage site of Lutina are well known to the general public and many of them belong to interesting places of national or supra-regional importance (e.g. the complex of the historical Salt Refinery in Prešov, etc.). However, many locations are little or not publicly available, but despite their regional significance, many of them are valuable from a natural or historical-cultural point of view.

The link between the pilgrimage site and the concept of an ecomuseum is a concept that can bring, on the one hand, instructions how to protect and enhance this heritage for the local community that should be the main bearer of this idea and, on the other hand, to present this heritage not only to pilgrims, who visit these places, but also to visitors arriving for other than spiritual reasons. The richness and diversity of the territory of Slovakia, however, does not orient these pilgrimage sites out of other important elements of the landscape and the tangible or intangible culture of the territory; so authors decided to place a pilgrimage site into the centre of the ecomuseum, but also to add natural and cultural-historical attractions in its surroundings to offer a more comprehensive view of the studied area.

Ecomuseums are a very varied form of protection and presentation of the territory's heritage; the creation of ecomuseum based on a pilgrimage site is an interesting option that can also get real contours. In this paper, however, authors wanted to point out first of all this opportunity and introduce such a model that can be applied in the future in pilgrimage sites not only within Slovakia, but also in other geographic areas that are significant in terms of religiosity.

\section{Acknowledgement}

This paper is realized as part of the project GaPU 32/2017 of the Grant Agency for PhD students and young scientific and pedagogical staff of the Prešov University in Prešov, Slovakia.

\section{References}

Borrelli, N., \& Davis, P. (2012). How Culture Shapes Nature: Reflections on Ecomuseum Practices. $\mathrm{Na}$ ture and Culture, 7(1), doi:10.3167/nc.2012.070103

Cohen, E. (1992). Pilgrimage and Tourism: Convergence and Divergence 'pp. 47-61 in A. Morinis (Ed.) Sacred Journeys: The Anthropology of Pilgrimage. Westport: Greenwood Press, 47-67 pp.

Collins-Kreiner, N. (2010). Researching pilgrimage: Continuity and transformations. Annals of tourism research, 37(2), 440-456.

Corsane, G., Davis, P., \& Murtas, D. (2009). Place, local distinctiveness and local identity: Ecomuseum approaches in Europe and Asia. In M. Anico \& E. Peralta (Eds.), Heritage and Identity. Engagement and Demission in the Contemporary World. (pp. 4762). Abingdon: Routledge.

Dancák, F. (2010). Lutina. Basilica and hill. Prešov: Petra. 127 pp. (in Slovak).

Davis, P. (2005). Places, 'cultural touchstones' and the ecomuseum. In G. Corsane (Ed.), Heritage, $\mathrm{Mu}$ seums and Galleries. An introductory reader. (pp. 402-415). London - New York: Routledge.

Davis, P. (2011). Ecomuseums. A Sense of Place. London: Continuum. 298 pp; and edition.

Ďurček, J., \& et al., (1991). Čergov - Branisko. Tourist guide of CSFR. Bratislava: Šport. 223 pp. (in Slovak).
Fekete, Š. (1947). The origin, distribution and importance of Slovak pilgrimage places. Ethnographic Yearbook, 8, 125-144. (in Slovak).

Fogaš, A., Rosič, M., \& Matlovič, R. (2015). Selected routes through eastern Slovakia. Excursion guidebook. Prešov: Vydavatel'stvo Prešovskej univerzity, 156 pp.

Harčár, J., Kandráčová, V., Matlovič, R., \& Michaeli, E. (1998). Prešov, Prešov District and Prešov Region. Geographic excursions. Prešov: Department of Geography and Geoecology FHNS PU, Východoslovenská pobočka SGS, Okresný úrad Prešov. 195 pp. (in Slovak).

Havlůjová, H. (2012). Heritage, Education and Sustainability. In D. Fotlýn \& H. Havlůjová (Eds.), Cultural Heritage and Sustainable Development of Local Communities. (pp. 10-27). Praha: Brontosauři ekocentrum Zelený klub. (in Czech).

Havlůjová, H., Foltýn, D., \& Charvátová, K. (2012). Education for relation to cultural heritage and education for sustainable development in the Czech Republic. Envigogika, 7(3), https://www.envigogika. cuni.cz/index.php/Envigogika/article/view/78/82 (23.10.2017) (in Czech). doi:10.14712/18023061.78

Hochmuth, Z., Lacová, A., \& Matlovič, R. (1994). Geography of Prešov. Prešov: PdF UPJŠ. 83 pp. (in Slovak). 
Jackowski, A. 200o. Religious Tourism - Problems with Terminology. Peregrinus Cracoviensis, 10, 63-74.

Klamár, R. (2012). Ecomuseums as a new phenomenon in the region development on the example of „Podoby ohňa“ ecomuseum. Folia Geographica, 20, 54, 111-127. (in Slovak with English summary).

Kónya, P. (2000). The history of Sabinov. Sabinov: Mestský úrad Sabinov, 533 pp. (in Slovak)

Krogmann, A. (2007). Religious tourism in the world. Nitra: UKF, 67 pp. (in Slovak)

Lenčiš, Š. (2000). Pilgrimage in the life of a believer. Prešov: Club of Christian Teachers in Prešov. 16 pp. (in Slovak).

Liszewski, S. (200o). Pilgrimages or Religious Tourism? Peregrinus Cracoviensis, 10, 47-52.

Lokaj, A. (2000). Hanigovce: Past and present. Hanigovce: Municipal office in Hanigovce. 104 pp. (in Slovak).

Maggi, M., \& Falletti, V. (200o). Ecomuseums in Europe. What they are and what they can be: Working paper. Torino: Istituto Ricerche Economico-sociali del Piemonte.

Matlovič, R. (2001). Geography of Religions. Prešov: FHNS. 375 pp. (in Slovak).

Matlovičová, K., Klamár, R., \& Mika, M. (2015). Tourism and its forms. Prešov: Prešovská univerzita $\mathrm{V}$ Prešove, 550 pp. (in Slovak)

Mayrand, P. (1985). The new museology proclaimed. Museum International, 37(4), 200-201. doi:10.1111/j.1468-0033.1985.tboo588.x

Michniak, D. (2014). Selected approaches to assessing transport accessibility in relation to tourism development. The Geographic Journal, 66(1), 21-38. (in Slovak).

Pavicic, J., Alfirevic, N., \& Batarelo, V.J. (2007). The management and marketing of religious sites, pilgrimage and religious events: challenges for Roman Catholic pilgrimages in Croatia. In R. Raj \& N.D. Morpeth (Eds.), Religious tourism and pilgrimage festivals management: An international perspective. (pp. 48-63). Wallingford: CABI Publishing. doi:10.1079/9781845932251.0048

Petrík, L. (2012). Greek-Catholic church in Slovakia. In Heritage of Sts. Cyril and Method. PETRA. Prešov: Petra. 379 pp. (in Slovak).

Rinschede, G. (1992). Forms of religious tourism. Annals of Tourism Research 19, 51-62.

Rivard, R. (2001). Ecomuseums in Quebec. Museum International, 53(4), 19-22.

SODB. (2011). The 2011 Population and Housing Census. https://census2011.statistics.sk/tabulky.html (visited 6.6.2017). (in Slovak).
Soljan, I. (2000). Sanctuaries and their effect on the organization of urban space based on the example of largest Catholic sanctuaries in Europe. Krakow: IGiGP UJ, 364 pp. (in Polish)

Stausberg, M. (2011). Religion and Tourism: Crossroads, destinations and encounters. London \& New York: Routledge, 279 pp.

Stoddard, R. (1997). Defining and Classifying Pilgrimages. Geoscience and Man 34, 41-6o.

Švorc, P., \& et al., (2003). Stories of Old Prešov. Prešov: Universum. 221 pp. (in Slovak).

Švorc, P., \& et al., (2006). Guide through historical Prešov. Universum. 173 pp. (in Slovak).

Tirpák, P., Dancák, F., \& Ostrowski, M. (2015). Homo viator et homo peregrinus: Basics of tourism and pilgrimage. Prešov: Vydavatel'stvo Prešovskej university. 207 pp. (in Slovak).

Turner, V., \& Turner, E. (1973). The center out there: Pilgrim's goal. History of Religions, 12(3), 191-230.

Uličný, F. (1990). History of the settlement of Šariš Region. Košice: Východoslovenské vydavatel'stvo. 513 pp. (in Slovak).

Verba, V., \& Pasternák, T. (2016). Greek-Catholic pilgrimage sites in Slovakia and attractions in their surroundings + hiking trails. Prešov: Petra. 158 pp. (in Slovak).

Verba, V., \& Pasternák, T. (2016). Greek Catholic Pilgrim Sites in Eastern Slovakia as a Tool for Raising Awareness of Local Wealth. In S. Paschrová \& M. Doležalová (Eds.), Current Tourism Issues: Local Wealth and Tourism (A Yearbook of the International Conference). (pp. 451-461). Jihlava: Vysoká škola polytechnická Jihlava. https://kcr.vspj.cz/historie-konferenci-kcr/konference-aktualni-problemy-cestovniho-ruchu-2016 (18.7.2017) (in Slovak).

Vukonic, B. (2006). Sacred places and tourism in the Roman Catholic tradition. In D.J. Timothy \& D. Olsen (Eds.), Tourism, Religion and Spiritual Journeys. (pp. 237-253). London - New York: Routledge. http:// shora.tabriz.ir/Uploads/83/cms/user/File/657/E_ Book/Tourism/Tourism\%2oReligion\%2oand\%20 Spiritual\%2oJourneys.pdf (9.7.2017).

Widawski, K. (2011). Selected elements of the cultural heritage of the rural environment - their use in tourism on the example of Spain and Poland. Wrocław: Uniwersytet Wrocławski. 266 pp. (in Polish).

Wiedermannová, O., Frohmann, W., \& Bazlerová, S. (2008). Sabinov city and its Jews. Prešov: DAH. 200 pp.

Internet 1. https://www.lutina.sk/historia-obce.html 